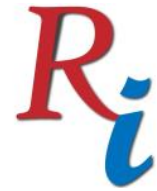

Asia Proceedings of Social Sciences

(APSS)

www.readersinsight.net/APSS

\title{
THE DEMOGRAPHIC SHIFTS IN WEST AFRICAN COUNTRIES: IMPLICATIONS FOR ACCESS TO HIGHER EDUCATION IN NIGERIA
}

\section{Muftahu Jibirin Salihu*}

National Higher Education Research Institute (NaHERI)

Universiti Sains Malaysia

Malaysia

muftahu@usm.my

\section{Hazri Jamil}

National Higher Education Research Institute (NaHERI)

Universiti Sains Malaysia

Malaysia

Hazri@usm.my

*Corrosponding author's Email: $\underline{\text { muftahu@usm.my }}$

Peer-review under responsibility of 4th Asia International Multidisciplinary Conference 2020 Scientific Committee http://connectingasia.org/scientific-committee/ (C) 2020 Published by Readers Insight Publisher, Office \# 6, First Floor, A \& K Plaza, Near D Watson, F-10 Markaz, Islamabad. Pakistan, editor@readersinsight.net

This is an open access article under the CC BY-NC-ND license (http://creativecommons.org/licenses/by-nc-nd/4.0/). 


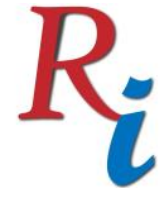

Asia Proceedings of Social Sciences

(APSS)

www.readersinsight.net/APSS

\section{A b s t r a c t}

Africa as a continent is so far the fastest growing in the entire world where the projections indicted that the population of the continent would increase by $50 \%$ in the next two decades. Presently, the population of the region stands at 1.2 billion and the West African states consist of $15 \%$ of the total number while Nigeria accounts for nearly 200 million people with $44 \%$ of the people under 15 years old. Consequently, the purpose of this research paper is to see how the demographic change has implications for access to the Nigerian higher education system with a specific focus on university education. In order to understand this phenomenon, this research engaged in secondary data analysis as a technique to obtain information in achieving the study's objectives. Subsequently, even though the total number of secondary school graduates or output was not accessible for this study, the analysed data from the Joint Admissions and Matriculation Board (JAMB) indicated that 1,687,551 and 1,557,017 students sat for university matriculation examinations in Nigeria for 2016 and 2017 academic sessions respectively, in which $97 \%$ of the candidates were seeking admission to universities specifically. Similarly, the data indicated that over $65 \%$ of the candidates have met the required points to be admitted into universities. On the other hand, data from the National Universities Commission (NUC) showed that there are a total of 91 public universities in Nigeria including both the federal and state universities with a capacity of less than 500,000, showing that more than $50 \%$ of the qualified students will be left unadmitted. Consequently, this study strongly recommends adequate demographic shift consideration while planning the national higher education policies in relation to access to university education and higher educational institutions in general.

Keywords: Demography, West African, Access, Higher Education, Nigeria

\section{Rese a r ch H i g h I igh t s}

Africa, like most of the developing continents in the world, has experienced rapid growth in its population and the index is expected to keep rising from now to the turn of the century. It is a known fact that from the time governments in Africa began achieving consensus, experts challenged the accuracy of the outcomes of enumeration exercises, claiming that the errors are too grievous to be overlooked or considered simple and manageable. The case has been almost the same throughout Africa and this is attributed to many factors including lack of expertise, ignorance, and nonchalant attitude among others. For instance, according to the Nigeria Demographic and Health Survey, there are cases where many people do not know their date of birth, especially among illiterate women - leaving the enumerators or interviewers or a household to guess the age. Other problems were due to the lack of efficient expertise by the enumerators. Thus, the reliability of such statistical analysis is doubtful, though no other more reliable source could be used (Odimegwu \& Kekovole, 2014). Whatever the case may be, 


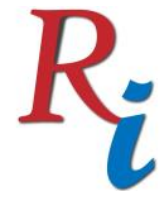

\section{Asia Proceedings of Social Sciences (APSS) \\ www.readersinsight.net/APSS}

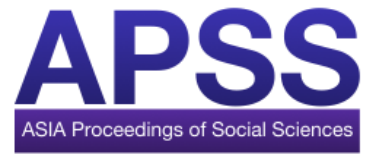

Africa will keep growing in its population for dividend or for debt, and the current population of 1.3 billion people will triple to 4.3 billion in the next 70 years (Cilluffo \& Ruiz, 2019).

Bearing this in mind, the population of Nigeria was 200 million in 2019 while it is 205.87 million in 2020. It is estimated to be around 210.87 million by 2021 and finally, the population will be 215.87 million by 2022. The increase is mostly among the children between 5 to 25 years old (Trading Economics, 2019). Narrowing the scale to the number of children in Nigeria, out of the total number of Nigerian people, $46 \%$ were children under the age of 15 (UNICEF, 2017). This implies that a great percentage of the population is within the age of higher education. More importantly, the number is more likely to increase in years to come. From now to 2050, the Nigerian population will double from 200 million to 400 million (The Economist, 2019) and by the end of the century, Nigeria will be leading all countries in Africa in producing more babies with an estimate of 864 million births and this is a bit above the expected fertility from China by 2070 (Cilluffo \& Ruiz, 2019). On the face of this, the growth of the population in Africa is to the benefit of its people, if the teaming population is driven to the path of economic and education development. But if untamed, the population will only increase the existing problems of the slow continent.

With this academic projection on the Nigerian population, a considerable number of young adults are aspiring to enrol in higher education programmes each year. These youth graduated from different secondary schools and their target is to get admission to one of the higher educational institutions in the country. The number of the secondary school graduates is on the increase at least for the fact that both the primary and secondary education are free and compulsory in Nigeria (Agboola \& Ofoegbu, 2010; Salihu, \& Jamil, 2015). Moreover, right from secondary school, students were oriented to different job opportunities and brighter life if they could obtain at least a university degree. Hence, the demand for furthering education in universities has been rocketing almost every year.

Due to the discrepancy in the exact total number of students graduating from secondary schools each year, some of them may not have the ambition or cannot afford to finance their further education or it is matter of distance between locality and available university within the catchment area. For some reason, it will not be as accurate to use the number of secondary school graduates as a yardstick to trace the implication for accessing higher education. Thus, to be on the safe side, this research will rely on the number of JAMB candidates in 2016 and 2017 as a case study.

Previous data obtained from the National Bureau of Statistics and JAMB indicated that between 2010 and 2015, there were no less than 10 million candidates who sat for the JAMB examinations across the country and out of this number, only $26 \%$ could secure admission. This means in five years, Nigerian universities could offer admission to only 2.6 million students while the remaining 7.4 million or $74 \%$ had to look for other academic alternatives (JAMB, 2019; Salihu et al., 2016). 


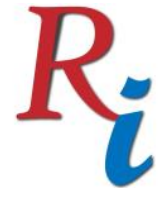

\section{Asia Proceedings of Social Sciences \\ (APSS) \\ www.readersinsight.net/APSS}

For 2016 and 2017 as the case study for this paper, there were 1,579,027 students who sat for the University and Tertiary Matriculation Examination [UTME] (WES Staff, 2017). The number of candidates was a bit higher the following year where 1,687,551 took the ComputerBased Test of JAMB. Though mass failure of students was recorded in 2016 UTME, mostly due to malfunction problems with the machines, there were still a few students among the successful candidates who could secure admission to one the Nigerian universities.

As at 2016, there were around 150 universities in Nigeria owned by the state and federal governments as well as the private ones, and the universities have the capacity of enrolling no more than 600,000 in an academic session (Kazeem, 2017). In that year, only 9,656 candidates got admission to the private universities and this was an insignificant number. As at 2018, out of 164 universities in Nigeria, 75 were privately owned but still they could only enrol less than $6 \%$ of students seeking admissions to the Nigerian universities (Adedigba, 2018). So, university students in Nigeria rely on public universities for their higher education and they will be the focus of this paper. The distribution of available universities in Nigeria is naturally uneven among the six regions of the country.

Beside the fact that these universities are overburdened, they are also not located evenly in the country. The uneven distribution reflects the degree of commitment and seriousness to the Western education by a region. South-east has the highest number of universities, followed by south-west, south-south, north-east, north-west, and lastly, North Central (Agboola \& Ofoegbu, 2010). Needless to say, the Christian-dominated regions lead in seeking Western education right from the primary to university while their Muslim counterparts in the north lagged behind (Adeyemi \& Edeki, 2018). Figures of the universities are always changing where currently, there are 170 universities in the country comprising 43 federal universities, 48 state universities, and 79 private universities (NUC, 2019). However, the additional figures do not practically influence the status quo of the higher education in Nigeria.

\section{Research Objectives}

The objectives of this research are:

- To understand the demographic change of college-age students in Nigeria and its implication for access to higher education.

- To identify suggestions towards addressing the implication of demography for access to university education in Nigeria.

\section{Purpose of the Study}

As the population of Africa is growing, though a bit more rapidly than its economy, and the highest age group of the people falls between 15 to 24 years old, it becomes necessary to examine the educational opportunities and vacancies these teaming youth have in higher 


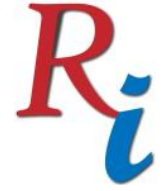

\section{Asia Proceedings of Social Sciences \\ (APSS) \\ www.readersinsight.net/APSS}

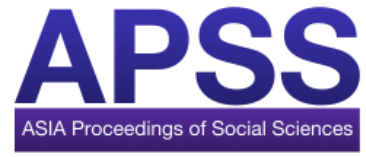

education. This research intends to examine the accessibility of higher education in subSaharan Africa with a specific focus on the Nigerian students from different secondary schools and coupled with a shortage of available capacity in universities for millions of applicants

\section{Methodology}

In conducting an educational research, there are some guiding principles that guarantee certain degree of effectiveness in achieving the desired research aims and objectives (Salihu, 2017). In order to understand this phenomenon, this research engaged in secondary data analysis as a technique to obtain information in achieving the study's objectives. Consequently, analysis of the data was made available by JAMB and NUC on the number of candidates who sat for the university examinations, the number of successful candidates, and those absorbed by the Nigerian universities. The paper will specifically focus on the JAMB statistics and NUC report on admission in 2016 and 2017. However, there will be a reflection on the situation in the previous years.

\section{Results and Findings}

The findings of the study indicated the need to establish more degree-awarding institutions across the country in order to bridge the existing gap between the number of applicants in the country and the available universities. Many colleges of education and polytechnics need to be affiliated to different universities in order to run degree programmes. It was indicated that it was the lack of available spaces in Nigerian universities that pushed Nigerians seeking university admission in foreign countries - affluent students looking for high-quality education will go to countries such as the United Kingdom and the United States. Those that are financially moderate and looking for accessibility to education will go to countries such as Malaysia, Ghana, South Africa, and Botswana, while others seeking certificates will go to Benin and Niger Republic. Due to this huge number of applicants, universities set more criteria for securing admission. For instance, chargeable post-UTME examinations are meant not only for extorting money from parents but also to limit the number of applicants that can get admission to the universities. Interestingly, newly established universities seeking candidates often ignore post-UTME tests and even reduce the cut-off mark for getting admission, which implies that the post-UTME tests are not meant for standardising education but reducing the number of intakes.

\section{REFERENCES}

Adedigba, A. (2018, July 10). Private universities account for less than $6 \%$ of Nigerian students population - NUC. Premium Times. Retrieved May 12, 2019, from https://www.premiumtimesng.com/news/more-news/275650-private-universitiesaccount-for-less-than-6-of-nigerian-students-population-nuc.html 


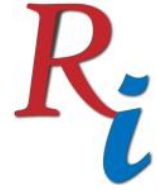

\section{Asia Proceedings of Social Sciences (APSS) \\ www.readersinsight.net/APSS}

Adeyemi, G., \& Edeki, S. O. (2018). Dataset on spatial distribution and location of universities in Nigeria. Data in Brief, 18, 1602-1608. https://doi.org/10.1016/j.dib.2018.04.093

Agboola, M. B., \& Ofoegbu, I. F. (2010, July 27). Access to university education in Nigeria: A review. University of Benin, Benin City, Edo State, Nigeria. https://files.eric.ed.gov/fulltext/ED511051.pdf

Cilluffo, A., \& Ruiz, N. G. (2019, June 17). World's population is projected to nearly stop growing by the end of the century. PEW Research Center. https://www.pewresearch.org/fact-tank/2019/06/17/worlds-population-isprojected-to-nearly-stop-growing-by-the-end-of-the-century/

Joint Admission and Matriculation Board, (2019) https://www.jamb.org.ng/ Accessed on $15^{\text {th }}$ of April 2019.

Kazeem, Y. (2017, February 22). Only one in four Nigerians applying to university will get a spot. Quartz. Retrieved May 12, 2020, from https:/qz.com/africa/915618/onlyone-in-four-nigerians-applying-to-university-will-get-a-spot/

National Universities Commission. (2019). Nigerian Universities. Retrieved from http://nuc.edu.ng/ Accessed on $15^{\text {th }}$ April 2019

Odimegwu, C. O., \& Kekovole, J. (Eds.). (2014). Continuity and change in Sub-Saharan African demography. New York: Routledge.

Salihu, M. J. (2017). Qualitative and quantitative debates in contemporary educational research. International Journal of Research in Educational Methodology, 7(5), 1323-1327. https://doi.org/10.24297/ijrem.v7i5.4343

Salihu, M. J., \& Jamil, H. (2015). Achieving equality of educational opportunity on access to university education in Nigeria: A case of policy implementation. Journal of International Cooperation in Education, 17(2), 3-22.

Salihu, M. J., Jamil, H., \& Ismail, A. (2016). Exploring institutional policies towards achieving macro policy of equal university admission: A case of a selected university in northwest Nigeria. International Research in Higher Education, 1(1), 170-178. https://doi.org/10.5430/irhe.v1n1p170

The Economist. (2019, March 26). Africa's population will double by 2050. The Economist. Retrieved May 11, 2019, from https://www.economist.com/specialreport/2020/03/26/africas-population-will-double-by-2050

Trading Economics. (2019, March 20). Nigeria population. Retrieved May 11, 2019, from https://tradingeconomics.com/nigeria/population 


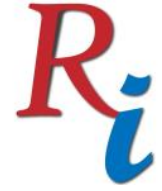

\section{Asia Proceedings of Social Sciences (APSS) \\ www.readersinsight.net/APSS}

UNICEF. (2017, July 08). Situation of women and children in Nigeria: Challenges faced by women and children in Nigeria. UNICEF. Retrieved May 11, 2020, from https://www.unicef.org/nigeria/situation-women-and-children-nigeria

WES Staff. (2017, March 7). Education in Nigeria. WENR. Retrieved from https://wenr.wes.org/2017/03/education-in-nigeria 